\title{
Article/Artigo
}

\section{Occurrence of positivity for Trypanosoma cruzi in triatomine from municipalities in Southeastern Brazil, from 2002 to 2004}

\author{
Ocorrência e positividade para Trypanosoma cruzi em triatomíneos de municípios da região \\ sudeste do Brasil, de 2002 a 2004
}

\begin{abstract}
Márcia Beatriz Cardoso de Paula ${ }^{1}$, Idessânia Nazareth da Costa ${ }^{2}$, Paula de Albuquerque Freitas ${ }^{2}$, Jean Ezequiel Limongi $^{1}$, Adalberto de Albuquerque Pajuaba Neto ${ }^{1}$, Rogério de Melo Costa Pinto ${ }^{3}$, Ana Lúcia Ribeiro Gonçalves ${ }^{2}$ and Julia Maria Costa-Cruz ${ }^{2}$
\end{abstract}

\begin{abstract}
Introduction: from an epidemiological point of view, more than 120 species of triatomine (Hemiptera, Reduviidae) are known. The occurrence and positivity for Trypanosoma cruzi in triatomines in 16 municipalities of the Triângulo Mineiro and Alto Paranaíba were evaluated from January 2002 to December 2004. Methods: the triatomines were captured basically according to the classic norms of the National Health Foundation. The parasitological exams of the triatomines were conducted according to the technique described by the Ministry of Health. During the study period, 990 specimens of triatomines were captured and of these, 771 could be examined. Results: five species were identified: Triatoma sordida, Panstrongylus diasi, Panstrongylus megistus, Panstrongylus geniculatus and Rhodnius neglectus. Triatoma sordida represented $71.5 \%$ of all the triatomines captured, followed by Panstrongylus megistus (18\%), Rhodnius neglectus (9.3\%), Panstrongylus diasi (0.8\%) and Panstrongylus geniculatus $(0.4 \%)$. Of the total number of triatomines examined, $2.7 \%$ were positive for Trypanosoma cruzi. Panstrongylus megistus was the species that presented the highest rates of infection by Trypanosoma cruzi (8.3\%), followed by Rhodnius neglectus (2.9\%) and Triatoma sordida (1.4\%). Conclusions: there is a need to adapt to new circumstances in epidemiology, with greater emphasis on entomological surveillance, since the potential for adaptation of secondary species of triatomines exists, especially where Chagas' disease is already under control.

Key-words: Triatomine. Chagas' disease. Epidemiology. Trypanosoma cruzi. Brazil.
\end{abstract}

\section{RESUMO}

Introdução: do ponto de vista epidemiológico mais de 120 espécies de triatomíneos (Hemiptera, Reduviidae) são conhecidas. A ocorrência e a positividade de Trypanosoma cruzi em triatomíneos de 16 municípios do Triângulo Mineiro e Alto Paranaíba foram avaliadas de janeiro de 2002 a dezembro de 2004. Métodos: os triatomíneos foram capturados seguindo basicamente as normas clássicas da Fundação Nacional de Saúde. Os exames parasitológicos dos triatomíneos foram conduzidos de acordo com a técnica descrita pelo Ministério da Saúde. Durante o período de estudo, foram capturados 990 exemplares de triatomíneos, sendo que 771 dos capturados estavam em condiçốes de serem examinados. Resultados: cinco espécies foram identificadas: Triatoma sordida, Panstrongylus diasi, Panstrongylus megistus, Panstrongylus geniculatus e Rhodnius neglectus. Triatoma sordida representou $71,5 \%$ de todos os triatomíneos capturados, seguido por Panstrongylus megistus (18\%), Rhodnius neglectus (9,3\%), Panstrongylus diasi (0,8\%) e Panstrongylus geniculatus $(0,4 \%)$. Dos triatomíneos examinados, $2,7 \%$ foram positivos para Trypanosoma cruzi. Panstrongylus megistus foi a espécie que apresentou a maior taxa de infecção por Trypanosoma cruzi (8,3\%), seguida pelo Rhodnius neglectus (2,9\%) e Triatoma sordida (1,4\%). Conclusões: há necessidade de se adequar às novas circunstâncias epidemiológicas com ênfase na vigilância entomológica, uma vez que o potencial de adaptação de espécies secundárias de triatomíneos, em áreas onde a doença de Chagas está controlada, é uma preocupação.

Palavras-chaves: Triatomíneos. Doença de Chagas. Epidemiologia. Trypanosoma cruzi. Brasil.

1. Regional Center of Zoonotic Diseases of Uberlândia, Department of Health of Uberlândia, Uberlândia, MG 2. Department of Immunology, Microbiology and Parasitology, Institute of Biomedical Sciences, Federal University of Uberlândia, Uberlândia, MG. 3. Faculty of Mathematics, Center of Exact Sciences and Technology, Federal University of Uberlândia, Uberlândia, MG.

Address to: Dra. Julia Maria Costa-Cruz. Laboratório de Parasitologia/ICBIM/UFU. Av. Pará 1720, 38400-902 Uberlândia, MG, Brazil.

Tel: 5534 3218-2187; Fax 5534 3218-2333

e-mail: costacruz@ufu.br

Received in 20/04/2009

Accepted in 16/12/2009

\section{INTRODUCTION}

From an epidemiological point of view, more than 120 species of triatomine (Hemiptera, Reduviidae) have already been identified. They are strictly hematophagous insects, generally with nocturnal habits and many are potential vectors of Chagas' disease (CD), an anthroponosis known as American trypanosomiasis ${ }^{1-3}$.

In Brazil, the control of $C D$ vectorial transmission was institutionalized by the National Malaria Service in 1950. An entomological survey, conducted between 1975 and 1983, demonstrated that of more than 42 species of triatomines identified in Brazil, 30 were detected in the domestic environment. Five of these were considered to be active in the transmission of Chagas: Triatoma infestans, Panstrongylus megistus, Triatoma brasiliensis, Triatoma pseudomaculata and Triatoma sordida ${ }^{4}$. Satisfactory results were obtained with the consolidation of control programs in relation to the domestic environment. The Triatoma infestans infestation was controlled and entomological surveillance of the secondary triatomine species was established ${ }^{5-8}$. In spite of the magnitude of the problems represented by $\mathrm{CD}$ and the proven efficacy of insecticides with residual action in the combat of the vector, control was only systematized and structured in a nationwide program in the 1970 's'. In July 2006, the elimination of vectorial transmission of CD by Triatoma infestans was certified in all states of Brazil. This process involved various actions, including the sanitization and inspection of residences. The result was a strong decrease in the number of children infected, as well as $100 \%$ control of contamination in blood banks as prevalence of the disease was reduced to $0.6 \%$ of the donors ${ }^{10}$. However other species of triatomine that are normally of secondary importance in the transmission of Trypanosoma cruzi in humans, have been captured with increasing frequency, and, surprisingly, in high densities within dwellings, due to the growing environmental changes caused by humans. 
Since 2000, the control of CD in the State of Minas Gerais occurs in a decentralized manner, as the municipalities assume the responsibility for implementing such activities. The responsibility for monitoring triatomines is the municipalities, which perform scheduled visits in homes. The municipality performs this function through visitations by a health worker who searches the residence and sprays when the presence of triatomines is confirmed ${ }^{11}$. The State of Minas Gerais received certification for eliminating CD through transmission by Triatoma infestans from the Pan American Health Organization in 2002. In addition, from 1989 to 2006, 34,000 samples of human sera originating from 408 municipalities were tested and less than $1 \%$ of samples presented positive results, demonstrating the absence of recent infection caused by triatomine bites. Most of the deaths, about $99.88 \%$, occurred in patients with chronic disease, aged 20 years-old or over, which means they are remnants of the period in which vectorial transmission had not yet been interrupted ${ }^{11}$.
The aim of this study was to evaluate the occurrence and positivity for Trypanosoma cruzi in triatomines in 16 municipalities of the Triângulo Mineiro and Alto Paranaiba region of Southeastern Brazil, from January, 2002 to December, 2004.

\section{METHODS}

\section{Study area}

The study area involved 16 municipalities in the Triângulo Mineiro and Alto Paranaiba region of the State of Minas Gerais, in Southeastern Brazil (Figure 1). Two of the 18 municipalities of the region were eliminated due to the nonexistence of data during the period. The region is part of the savanna or cerrado ecosystem. It is an area that has suffered great environmental impact during the last few decades due to unplanned urban growth. The native cerrado vegetation has been mostly substituted by cattle and

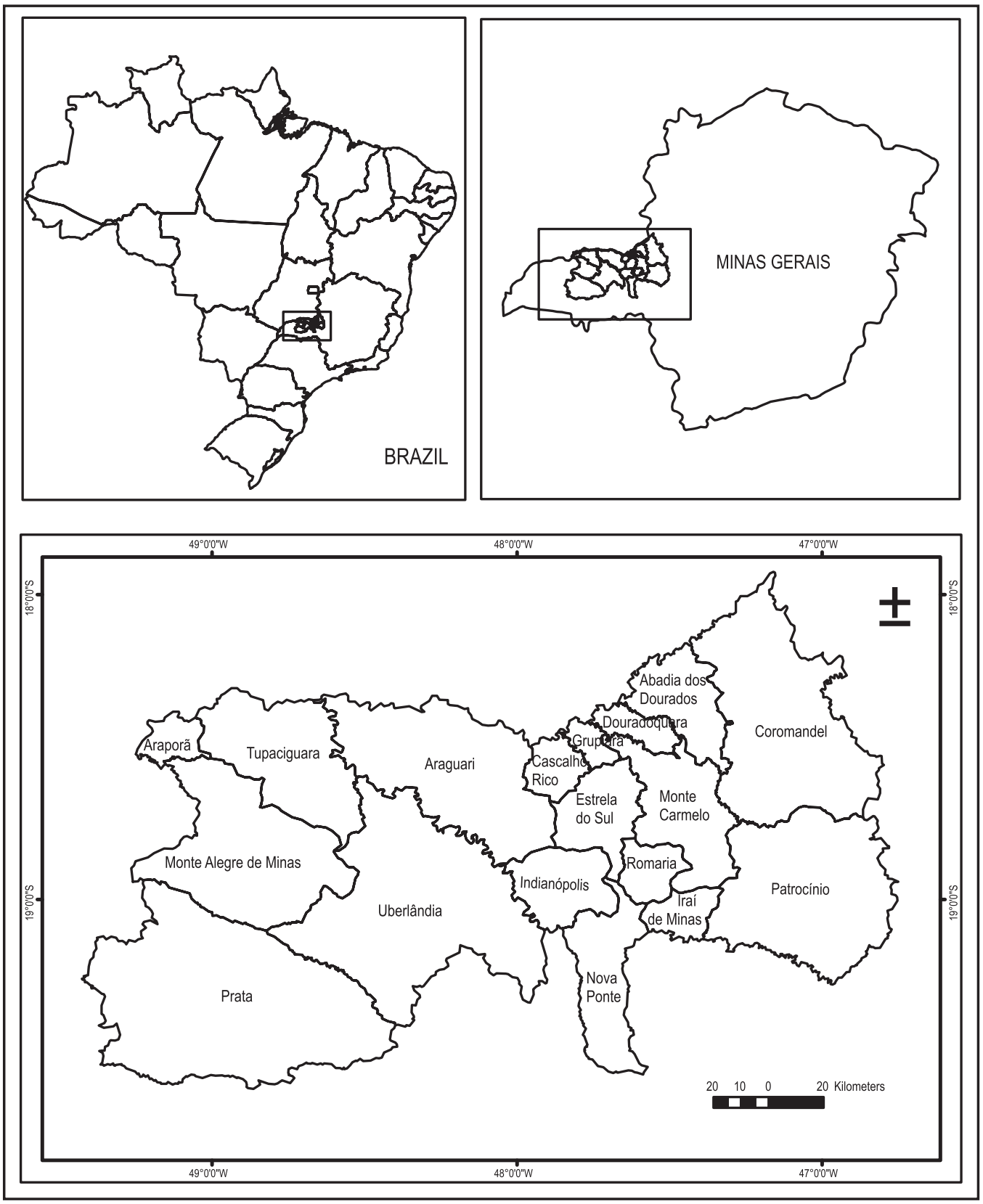

FIGURE 1 - Area covered by the Regional Health Administration of Uberlândia-Minas Gerais, Brazil. 
crops, corn and soybeans, which have created extensive ecological imbalance.

The data referring to 16 municipalities were obtained from the Epidemiological Information Center in Uberlândia. This center is part of the State Health Department (SHD). Of the municipalities studied, only seven provided integral surveillance and systematic combat of triatomine. The governmental control programs were less effective in the other municipalities.

The triatomines were captured basically according to the classic norms of the National Health Foundation (Fundação Nacional de Saúde, FUNASA) ${ }^{12}$ and refined by the Technical Management in CD SHDMG. The triatomines were captured in three ways: 1 ) Reporting bugs: a service performed by the population, involving handing the suspected insect in to a Triatominae Information Center (TIC) installed at strategic locations in the municipalities, such as schools and health centers; 2) Notification service: performed by staff working in the Chagas' Disease Control Program (ChDCP) for each municipality, 3) Active searches: the search for vectors was conducted in households in the municipality, regardless of whether the population had performed any searches or registered any complaints. The households consisted of the house and annexes and other buildings (chicken run, rubbish dump, etc). The residents were advised by staff of the $\mathrm{ChDCP}$ concerning the likely places to find the insects and instructed on how to capture them with due care and send them to the nearest TIC.

\section{Parasitological exams}

After external morphological analysis of the triatomines, the specimens were identified according to growth stage, sex, genus and species. The insects that presented intestinal content were forwarded for feces examination to test for the presence of Trypanosoma cruzi. The parasitological exams of the triatomines were conducted according to the technique described by the Brazilian Ministry of Health $^{13}$. The last abdominal segments of each triatomine were gently squeezed with tweezers and the fecal matter collected on a 25 by
$75 \mathrm{~mm}$-diameter microscope slide. The material was homogenized in an isotonic solution of $0.9 \% \mathrm{NaCl}$, thin smears were obtained and colored with methylene blue for $1 \mathrm{sec}$. They were then washed with buffered water to remove excess stain. Subsequently, the smear was covered with freshly prepared Giemsa solution (7 drops of Giemsa/5ml solution in buffered water), for $30 \mathrm{~min}$. After this period the slides were stored at room temperature in an inclined position, dried and the excessive coloring removed, until the moment of microscopic examination of the material, using 100X objectives and immersed in oil.

\section{Statistical analysis}

The Student $t$ test was applied to verify any numerical differences for captured triatomines between the municipalities with systematic epidemiological surveillance and those that did not have such programs. Municipal comparisons were elaborated using the MannWhitney nonparametric test. The Binomial nonparametric test was used to compare proportions of positive exams between the municipalities evaluated ${ }^{14}$. The significance level was established at $\mathrm{p}<0.05$.

\section{RESULTS}

During the period studied, 990 specimens of triatomines were captured. The intestinal content of 771 specimens was examined, representing $78 \%$ of the total. The remaining specimens were dry and did not present intestinal contents (Table 1). Triatomines positive for Trypanosoma cruzi were detected in 50\% of the 16 municipalities studied.

The municipalities that conducted systematic control activity were $48 \%$ of the regional total. The majority 762 (77\%) of triatomines captured came from these municipalities. A significant difference $(p=0.0017)$ was observed between the number of triatomines captured in the cooperating municipalities and those that did not have systematic control. A significant difference $(p=0.0027)$ was

TABLE 1 - Numbers of triatomine captured, identified and examined as positive for Trypanosoma cruzi in 16 municipalities of the Uberlândia, Minas Gerais Regional Health Administration, during the period between January 2002 and December 2004.

\begin{tabular}{|c|c|c|c|c|c|c|c|c|c|c|c|c|}
\hline \multirow[b]{2}{*}{ Municipalities } & \multicolumn{3}{|c|}{2002} & \multicolumn{3}{|c|}{2003} & \multicolumn{3}{|c|}{2004} & \multicolumn{3}{|c|}{ Total } \\
\hline & $\mathrm{NC}$ & $\mathrm{NE}$ & Pos & $\mathrm{NC}$ & $\mathrm{NE}$ & Pos & $\mathrm{NC}$ & $\mathrm{NE}$ & Pos & $\mathrm{NC}$ & $\mathrm{NE}$ & Pos \\
\hline Araporã* & 0 & 0 & 0 & 11 & 12 & 0 & 182 & 148 & 2 & 193 & 160 & 2 \\
\hline Patrocínio* & 75 & 64 & 8 & 22 & 8 & 0 & 21 & 15 & 0 & 120 & 87 & 8 \\
\hline Tupaciguara* & 13 & 13 & 0 & 7 & 2 & 0 & 90 & 73 & 1 & 110 & 88 & 1 \\
\hline Araguari* & 19 & 14 & 0 & 55 & 43 & 1 & 30 & 30 & 0 & 104 & 87 & 1 \\
\hline Douradoquara & 25 & 19 & 0 & 41 & 28 & 2 & 34 & 24 & 1 & 100 & 71 & 3 \\
\hline Uberlândia* & 14 & 12 & 1 & 37 & 25 & 1 & 48 & 46 & 2 & 99 & 83 & 4 \\
\hline Prata* & 0 & 0 & 0 & 41 & 37 & 0 & 53 & 43 & 1 & 94 & 80 & 1 \\
\hline Monte Carmelo* & 6 & 6 & 0 & 6 & 3 & 0 & 30 & 18 & 0 & 42 & 27 & 0 \\
\hline Abadia dos Dourados & 19 & 10 & 0 & 5 & 4 & 0 & 9 & 4 & 0 & 33 & 18 & 0 \\
\hline Indianópolis & 22 & 19 & 0 & 4 & 3 & 0 & 4 & 4 & 0 & 29 & 26 & 0 \\
\hline Coromandel & 2 & 1 & 0 & 13 & 3 & 0 & 5 & 3 & 0 & 20 & 7 & 0 \\
\hline Grupiara & 5 & 5 & 1 & 12 & 11 & 0 & 3 & 0 & 0 & 20 & 16 & 1 \\
\hline Estrela do Sul & 0 & 0 & 0 & 8 & 6 & 0 & 5 & 4 & 0 & 13 & 10 & 0 \\
\hline Irai de Minas & 0 & 0 & 0 & 6 & 5 & 0 & 3 & 2 & 0 & 9 & 7 & 0 \\
\hline Nova Ponte & 0 & 0 & 0 & 2 & 2 & 0 & 1 & 1 & 0 & 3 & 3 & 0 \\
\hline Cascalho Rico & 0 & 0 & 0 & 1 & 1 & 0 & 0 & 0 & 0 & 1 & 1 & 0 \\
\hline Total & 200 & 163 & 10 & 271 & 193 & 4 & 518 & 415 & 7 & 990 & 771 & 21 \\
\hline
\end{tabular}

*Municipalities that conducted systematic surveillance action and combat of triatomine in the Chagas' Disease Control Program.

NC: Number of triatomine captured; NE: Number of triatomine examined; Pos: Positive 
also verified between the number of triatomines examined from cooperating municipalities and those without systematic control. The relation between the number of positive and examined triatomines, in the cooperating municipalities and those without systematic control, was compared, with no significant differences.

Five species were identified: Triatoma sordida, Panstrongylus diasi, Panstrongylus megistus, Panstrongylus geniculatus and Rhodnius neglectus (Table 2). There was a predominance of Triatoma sordida (71.5\%) of the captured specimens, followed by Panstrongylus megistus (18\%), Rhodnius neglectus (9.3\%), Panstrongylus diasi (0.8\%) and Panstrongylus geniculatus (0.4\%). Of the total number of insects captured, 684 (69.1\%) specimens came from the peridomicile area and 306 (30.9\%) from the dwelling itself. Triatoma sordida was the species most frequently captured in the peridomicile area $(82.2 \%)$ and in the intradomicile area $(47.7 \%)$.
Of the total number of triatomines examined, $2.7 \%$ were positive for Trypanosoma cruzi. Among the insects captured in the intradomicile area, $3.4 \%$ of the positive specimens for Trypanosoma cruzi were Rhodnius neglectus, $2.9 \%$ were Triatoma sordida and $2.3 \%$ were Panstrongylus megistus. The species that presented the highest rate of infection by Trypanosoma cruzi was Panstrongylus megistus (8.3\%), followed by Rhodnius neglectus (2.9\%) and Triatoma sordida (1.4\%). The other species examined did not present Trypanosoma cruzi infection.

Table 3 shows the identification of the triatomines captured, examined and those positive for Trypanosoma cruzi, distributed throughout the area studied. Specimens of Panstrongylus megistus and Triatoma sordida were captured in 14 (87.5\%) of the 16 municipalities that conducted entomological surveillance. Specimens of Rhodnius neglectus were captured in $13(81.3 \%)$ of these municipalities.

TABLE 2 - Localization of the five triatomine species captured, examined and positive for Trypanosoma cruzi in 16 municipalities of the Uberlandia, Minas Gerais Regional Health Administration, during the period between January, 2002 and December, 2004.

\begin{tabular}{|c|c|c|c|c|c|c|c|c|c|c|c|c|c|c|c|}
\hline \multirow[b]{3}{*}{ Genus/specie } & \multicolumn{5}{|c|}{ Peridomiciliar } & \multicolumn{5}{|c|}{ Intradomiciliar } & \multicolumn{5}{|c|}{ Total } \\
\hline & \multicolumn{2}{|c|}{ captured } & \multicolumn{3}{|c|}{ examined } & \multicolumn{2}{|c|}{ captured } & \multicolumn{3}{|c|}{ examined } & \multicolumn{2}{|c|}{ captured } & \multicolumn{3}{|c|}{ examined } \\
\hline & $\mathrm{n}$ & $\%$ & pos & $\mathrm{n}$ & $\%$ & $\mathrm{n}$ & $\%$ & pos & $\mathrm{n}$ & $\%$ & $\mathrm{n}$ & $\%$ & pos & $\mathrm{n}$ & $\%$ \\
\hline Triatoma sordida & 562 & 82.2 & 5 & 461 & 1.1 & 146 & 47.7 & 3 & 102 & 2.9 & 708 & 71.5 & 8 & 563 & 1.4 \\
\hline Panstrongylus diasi & 1 & 0.1 & 0 & 1 & 0 & 7 & 2.3 & 0 & 5 & 0 & 8 & 0.8 & 0 & 6 & 0 \\
\hline Panstrongylus megistus & 107 & 15.7 & 10 & 90 & 11.1 & 71 & 23.2 & 1 & 43 & 2.3 & 178 & 18 & 11 & 133 & 8.3 \\
\hline Panstrongylus geniculatus & 1 & 0.1 & 0 & 0 & 0 & 3 & 1.0 & 0 & 1 & 0 & 4 & 0.4 & 0 & 1 & 0 \\
\hline Rhodnius neglectus & 13 & 1.9 & 0 & 10 & 0 & 79 & 25.8 & 2 & 58 & 3.4 & 92 & 9.3 & 2 & 68 & 2.9 \\
\hline Total & 684 & 69.1 & 15 & 562 & 2.7 & 306 & 30.9 & 6 & 209 & 2.9 & 990 & 100 & 21 & 771 & 2.7 \\
\hline
\end{tabular}

$\mathrm{n}$ : number of triatomine captured or examined; pos: positive

TABLE 3 - Genus and species of triatomine captured, examined and positive for Trypanosoma cruzi in 16 municipalities covered by the Uberlândia-Minas Gerais Regional Health Administration during the period between January 2002 to December 2004.

\begin{tabular}{|c|c|c|c|c|c|c|c|c|c|c|c|c|c|c|c|c|c|c|}
\hline \multirow{2}{*}{$\begin{array}{l}\text { Genus/sp } \\
\text { Municipalities }\end{array}$} & \multicolumn{3}{|c|}{$\begin{array}{l}\text { Triatoma } \\
\text { sordida }\end{array}$} & \multicolumn{3}{|c|}{$\begin{array}{c}\text { Panstrongylus } \\
\text { diasi }\end{array}$} & \multicolumn{3}{|c|}{$\begin{array}{c}\text { Panstrongylus } \\
\text { megistus }\end{array}$} & \multicolumn{3}{|c|}{$\begin{array}{l}\text { Panstrongylus } \\
\text { geniculatus }\end{array}$} & \multicolumn{3}{|c|}{$\begin{array}{l}\text { Rhodnius } \\
\text { neglectus }\end{array}$} & \multicolumn{3}{|c|}{ Total } \\
\hline & $\mathrm{NC}$ & NE & pos & $\mathrm{NC}$ & $\mathrm{NE}$ & pos & $\mathrm{NC}$ & $\mathrm{NE}$ & pos & $\mathrm{NC}$ & $\mathrm{NE}$ & pos & $\mathrm{NC}$ & $\mathrm{NE}$ & pos & $\mathrm{NC}$ & $\mathrm{NE}$ & pos \\
\hline Araporã ${ }^{*}$ & 191 & 158 & 2 & 2 & 2 & 0 & - & - & - & - & - & - & - & - & - & 193 & 160 & 2 \\
\hline Patrocínio* & 4 & 3 & 0 & 1 & 1 & 0 & 104 & 76 & 8 & - & - & - & 11 & 7 & 0 & 120 & 87 & 8 \\
\hline Tupaciguara* & 103 & 82 & 1 & - & - & - & 3 & 3 & 0 & - & - & - & 4 & 3 & 0 & 110 & 88 & 1 \\
\hline Douradoquara & 70 & 46 & 2 & - & - & - & 5 & 4 & 1 & 1 & 0 & 0 & 24 & 21 & 0 & 100 & 71 & 3 \\
\hline Uberlândia* & 71 & 59 & 2 & 5 & 3 & 0 & 7 & 7 & 1 & - & - & - & 16 & 14 & 1 & 99 & 83 & 4 \\
\hline Prata* & 81 & 68 & 0 & - & - & - & 11 & 10 & 1 & - & - & - & 2 & 2 & 0 & 94 & 80 & 1 \\
\hline Monte Carmelo* & 28 & 17 & 0 & - & - & - & 11 & 7 & 0 & - & - & - & 3 & 3 & 0 & 42 & 27 & 0 \\
\hline Abadia dos Dourados & 15 & 7 & 0 & - & - & - & 2 & 2 & 0 & - & - & - & 16 & 9 & 0 & 33 & 18 & 0 \\
\hline Indianópolis & 24 & 22 & 0 & - & - & - & 4 & 3 & 0 & - & - & - & 1 & 1 & 0 & 29 & 26 & 0 \\
\hline Grupiara & 15 & 12 & 0 & - & - & - & 1 & 1 & 0 & - & - & - & 4 & 3 & 1 & 20 & 16 & 1 \\
\hline Estrela do Sul & 12 & 9 & 0 & - & - & - & 1 & 1 & 0 & - & - & - & - & - & - & 13 & 10 & 0 \\
\hline Irai de Minas & 1 & 0 & 0 & - & - & - & 7 & 6 & 0 & - & - & - & 1 & 1 & 0 & 9 & 7 & 0 \\
\hline Nova Ponte & - & - & - & - & - & - & 1 & 1 & 0 & - & - & - & 2 & 2 & 0 & 3 & 3 & 0 \\
\hline Cascalho Rico & 1 & 1 & 0 & - & - & - & - & - & - & - & - & - & - & - & - & 1 & 1 & 0 \\
\hline Total & 708 & 563 & 8 & 8 & 6 & $\mathbf{0}$ & 178 & 133 & 11 & 4 & 1 & $\mathbf{0}$ & 92 & 68 & 2 & 990 & 771 & 21 \\
\hline
\end{tabular}

*Municipalities that conducted systematic surveillance action to combat triatomine in the Chagas' Disease Control Program. NC: number of triatomine captured. NE: number of triatomine examined.

NC: number of triatomine captured, NE: number of triatomine examined, pos: number of triatomine examined and identified as positive for Trypanosoma cruzi. 


\section{DISCUSSION}

Chagas' disease became a zoonotic disease when the traditional vectors, native to natural areas, were dislocated from their original wild ecotypes to human surroundings. The presence of the triatomines in dwellings occurred due to land use changes, such as clearing for crops, which has become prevalent in the region. Economic distortions and social differences also produce consequences that promote Trypanosoma cruzi transmission. In most areas where the insects have become prevalent, dwellings are precarious, incomes are obviously very low and social conditions are lamentable ${ }^{1,15}$.

The persistence of residual foci of Triatoma infestans in some Brazilian states, as well as the existence of a large number of autochthonous species that are potential vectors commonly found within dwellings (Panstrongylus megistus, Triatoma brasiliensis, Triatoma pseudomaculata and Triatoma sordida), represent risk factors for $\mathrm{CD}$ transmission. In addition, sporadic cases of oral transmission have been reported ${ }^{16-18}$.

In the State of Minas Gerais, of the 853 municipalities, 345 (40.4\%) are under epidemiological surveillance. However, in the year 2008, 517 municipalities were surveyed by the ChDCP. Considering this number, $66.7 \%$ of the municipalities conduct disease surveillance (ML Ferraz: Unpublished Data). Our findings permit the inference that municipalities with systematic control programs demonstrate proven efficiency. It is important to highlight that due to the low transmission levels of CD and the emergence of other diseases, such as dengue fever, political-administrative questions concerning systematic control programs have been neglected. To maintain these programs, direct support by the municipalities in sustaining their individual programs is necessary, together with the cooperation of the authorities. Unfortunately the National Endemic Control Program of the FUNASA has been discontinued ${ }^{8}$.

The epidemiological surveillance of $\mathrm{CD}$ in the central-western region of the State of Minas Gerais, based on knowledge and practice among municipal health agents working in the CD programs of surveillance and control was examined by Villela et al ${ }^{19}$. Thirty-five municipalities were visited, involving meetings and the application of a questionnaire pertaining to the knowledge, practice and difficulties of surveillance programs. Analysis of this data showed that 26 agents were employed on temporary (annual) contracts and only two had career stability. Of the agents surveyed, $77.1 \%$ commented that the local population had difficulty in identifying the vector insects (triatomines). Twenty-three agents stated that the municipal governments provided adequate conditions for conducting surveillance programs, however 27 mentioned problems, particularly requesting more educational materials, better wages and greater appreciation of their work by the municipal authorities.

In the present study, the species most frequently detected in the dwellings was Triatoma sordida, also considered the prevailing species in the State of Mato Grosso do Sul ${ }^{20}$. Triatoma sordida was also the species most frequently captured in the City of Uberlândia. This study is in agreement with research conducted by Silveira et $\mathrm{al}^{4}$, who captured and identified in residences, the following species: Triatoma infestans, Triatoma sordida, Panstrongylus megistus and Rhodnius neglectus, in the same city. In 2004, Macêdo and Marçal Júnior ${ }^{21}$ registered the presence of Triatoma sordida and Rhodnius neglectus in dwellings investigated by the authors in the region of
Olhos d'Agua, a rural district of Uberlândia. Triatoma sordida usually occupies places where Triatoma infestans has been eliminated due to the residual effects of the insecticides adopted by the control programs. This species, as well as Panstrongylus megistus, has been captured in both wild and urban ecotopes, frequently constituting domestic colonies ${ }^{15,22,23}$. In other studies, however, this species presented low rates of positivity for Trypanosoma cruzi, probably because it prefers to feed on the blood of birds ${ }^{1,24}$. In the present study, $1.4 \%$ of the total of positive triatomine were Triatoma sordida, thus constituting the third most prominent species for rates of positivity for Trypanosoma cruzi. For this reason Triatoma sordida should be the object of continuous monitoring.

In the present study, the primary habitat of Rhodnius neglectus, the second most captured species in the intradomicile area, was palm tree leaves ${ }^{1}$. The invasion of this wild species into human dwellings, with the risk of transmission of Trypanosoma cruzi, may have occurred due to the lack of ecological equilibrium caused by deforestation ${ }^{25}$.

In Minas Gerais, Panstrongylus megistus, second most captured species in the present study, has also been identified as the species most frequently detected in dwellings in studies conducted by Villela et $\mathrm{al}^{8}$. Panstrongylus megistus is considered to be the vector of the strongest epidemiological importance in Brazil due to its wide geographical distribution, high colonization capacity, domiciliation and adaptation to various sources of food and high susceptibility to Trypanosoma cruzi. Following the elimination of Triatoma infestans in MG, Panstrongylus megistus became the most important vector for $\mathrm{CD}$ in the western part of the state, where adult insects, in particular fecundated females, have been captured in the immediate vicinity of houses ${ }^{1,8,26}$

In conclusion, there is a need to adapt to new circumstances in epidemiology, with greater emphasis on entomology surveillance, since the potential for adaptation of secondary species of triatomines exists, especially where Chagas' disease is already under control.

This fact corresponds to the renewed risk of the establishment of a new transmission focus, especially in the domicile environment, since these species may occupy the place of the eliminated species. Given these factors, we believe it is important to maintain entomological surveillance in the study area.

\section{CONFLICT OF INTEREST}

None of the authors of this paper has a financial or personal relationship with other people or organizations that could inappropriately influence or bias the content of the paper.

\section{REFERENCES}

1. Dias JCP. Epidemiologia. In: Brener Z, Andrade Z, Barral-Neto M (orgs) Trypanosoma cruzi e Doença de Chagas, 2a edição. Rio de Janeiro: Guanabara Koogan, 2000; p. 54.

2. Dias JCP. Southern Cone Initiative for the elimination of domestic populations of Triatoma infestans and the interruption of transfusional Chagas disease. Historical aspects, present situation, and perspectives. Mem Inst Oswaldo Cruz 2007; 102 (suppl I):11-18.

3. Gourbière S, Dumonteil E, Rabinovich JE, Minkoue R Menu F. Demographic and dispersal constraints for domestic infestation by non-domicilated Chagas disease vectors in the Yucatan Peninsula, Mexico. Am J Trop Med Hyg 2008 78:133-139. 
4. Silveira AC, Feitosa VR, Borges R. Distribuição de triatomíneos capturados no ambiente domiciliar, no período de 1975/83, Brasil. Rev Bras Malariol Doenças Trop 1984; 36:15-312.

5. Ramos Jr NA, Carvalho DM. Os diferentes significados da certificação conferida ao Brasil como estando livre da doença de Chagas. Cad Saúde Publ 2001; 17:1403-1412

6. Silva RA, Bonifácio PR, Wanderley DMV. Doença de Chagas no Estado de São Paulo: comparação entre pesquisa ativa de triatomíneos em domicílios e notificação de sua presença pela população em área sob vigilância entomológica. Rev Soc Bras Med Trop 1999; 32: 653-659.

7. Tauil PL. Perspectivas de controle de doenças transmitidas por vetores no Brasil. Rev Soc Bras Med Trop 2006; 39:275-277.

8. Villela MM, Souza JMB, Mello VP, Azeredo BVM, Dias JCP. Vigilância entomológica de doenças de Chagas na região Centro-Oeste de Minas Gerais, Brasil, entre os anos de 2000 e 2003. Cad Saúde Públ 2005; 21:878-886.

9. Vinhaes MC, Dias JCP. Doença de Chagas no Brasil. Cad Saúde Públ 2000;16 (supl II):7-12.

10. Dias JCP. Doença de Chagas: sucessos e desafios. Cad Saúde Publ 2006; 22:2020 2020.

11. Centro de Pesquisas René Rachou. Transmissão da doença de Chagas está erradicada em Minas. Belo Horizonte, 2009. Disponível em http://www. cpqrr.fiocruz.br/pt-br/transmissao+chagas+erradicada+mg, acesso em 15 set. 2009.

12. SUCAM (Superintendência de Campanhas de Saúde Pública). Manual de normas técnicas da campanha de controle da doença de Chagas. Brasília: Ministério da Saúde; 1980.

13. Ministério da Saúde. Divisão de Doenças de Chagas. Manual de Normas Sobre Organização e Funcionamento de Laboratórios de Diagnóstico da Doença de Chagas. Centro de documentação do Ministério da Saúde, Brasília; 1981.

14. Gibbons JD. Nomparametric Statistical Inference, $4^{\text {th }}$ edition. New York: Mc Graw Hill Book Company; 2003.

15. Silveira AC. Situação do controle da transmissão vetorial da doença de Chagas nas Américas. Cad Saúde Públ 2000; 16 (supl II):35-42.

16. Guilherme ALF, Pavanelli GC, Silva SV, Costa AL, Araújo SM. Secondary triatomine species in dwellings and other nearby structures in municipalities under epidemiological surveillance in the state of Paraná, Brazil. Rev Panam Salud Publ 2001; 9:385-392.

17. Ministério da Saúde. Consenso Brasileiro em Doença de Chagas. Rev Soc Bras Med Trop 2005; 38 (supl III):5-29.

18. Silveira AC, Rezende DF, Nogales AM, Cortez-Escalante JJ, Castro C, Macedo V. Avaliação do sistema de vigilância entomológica da doença de Chagas com participação comunitária em Mambaí e Buritinópolis, Estado de Goiás. Rev Soc Bras Med Trop 2009; 42:39-46.

19. Villela MM, Souza JMB, Mello VP, Dias JCP. Vigilância epidemiológica da doença de Chagas em programa descentralizado: avaliação de conhecimento e práticas de agentes municipais em região endêmica de Minas Gerais, Brasil. Cad Saúde Públ 2007; 23:2428-2438.

20. Almeida PS, Ceretti Jr W, Obara MT, Santos HR, Barata JMS, Faccenda O. Levantamento da fauna de Triatominae (Hemiptera: Reduviidae) em ambiente domiciliar e infecção natural por Trypanosomatidae no Estado de Mato Grosso do Sul. Rev Soc Bras Med Trop 2008; 41:374-380.

21. Macêdo HS, Marçal Jr O. Distribuição de vetores da doença de Chagas em nível domiciliar: um estudo na zona rural de Uberlândia (MG). Cam Geogr 2004;5:50-66.

22. Oliveira AWS, Silva IG. Distribuição geográfica e indicadores entomológicos de triatomíneos sinantrópicos capturados no Estado de Goiás. Rev Soc Bras Med Trop 2007; 40:204-208.

23. Silva RA, Sampaio SMP, Koyanagui PH, Poloni M, Carvalho ME, Rodrigues VLCC. Infestação por triatomíneos em assentamento e reassentamento rurais na Região do Pontal do Paranapanema, Estado de São Paulo. Rev Soc Bras Med Trop 2007; 40:527-532.

24. Diotaiuti L, Azeredo BVM, Busek SCU, Fernandes AJ. Control of Triatoma sordida in the rural peridomestic environment of Porteirinha municipality, Minas Gerais, Brazil. Rev Panam Salud Publ 1998; 3:21-25.

25. Gurgel-Gonçalves R, Duarte MA, Ramalho ED, Palma ART, Romana CA, CubaCuba CA. Distribuição espacial de populações de triatomíneos (Hemiptera:
Reduviidae) em palmeiras da espécie Mauritia flexuosa no Distrito Federal, Brazil. Rev Soc Bras Med Trop 2004; 37:241-247.

26. Villela MM, Aleixo A, Souza JMB, Mello VP, Dias JCP. Nota sobre borrifação integral seguida de pesquisa, como estratégia de vigilância epidemiológica da doença de Chagas, em áreas de recrudescência de focos domiciliares de triatomíneos. Rev Soc Bras Med Trop 2006; 39:227-229. 